PAWE $ヒ$ ARMADA

Instytut Nauk Politycznych i Stosunków Międzynarodowych UJ

\title{
Fala Hobbesa: autor Lewiatana w ujęciu Leo Straussa
}

$\mathbf{T}$ homas Hobbes (1588-1679) został odczytany przez Leo Straussa (18991973) jako jeden z głównych myślicieli „pierwszej fali nowoczesności”. Jego dzieło - uznane za rzeczywisty fundament liberalizmu - wpisuje się zatem w schemat narracji historyczno-filozoficznej, służącej orientowaniu się w genealogii „kryzysu naszych czasów”, przy czym kolejne dwie „fale” znajdują swoją „polityczną implikację" w rozwiązaniach ustrojowych przyjętych, odpowiednio, przez komunistów i nazistów. Dla Straussa nowoczesność jest w istocie wolicjonalnym projektem myśli ludzkiej, którego fatalna kulminacja zawiera się w „zapomnieniu wieczności”, utracie wiary w rozpoznanie tego, co dobre, odmowie rozróżnienia między sprawiedliwym i niesprawiedliwym porządkiem ${ }^{1}$. Punkt zapalny kryzysu znajduje się po stronie filozofii politycznej w jej nowym, uzurpatorskim wydaniu - dokonań teoretyków żonglujących autorytatywną wizją powszechnego zbawienia „tu i teraz”.

Za faktycznego, świadomego twórcę tej nowej filozofii Strauss uznaje Niccola Machiavellego. Postać ta niewątpliwie budzi w nim fascynację, stając się przedmiotem niezwykle jaskrawego, a stopniowo problematyzowanego osądu (rozwijanego na podstawie „staromodnej i prostej opinii”): Machiavelli to - według Straussa - „nauczyciel zła” ${ }^{2}$. Jednak uważny czytelnik dostrzeże swego rodzaju skryte uwielbienie dla odwagi i subtelności jego myśli czy

Por. L. Strauss, Trzy fale nowożytności, przeł. W. Madej, „Przegląd Polityczny” 2007, nr 84 (przedruk z: „Res Publica” 1988, nr 11), s. II; Czym jest filozofia polityki?, [w:] tegoż, Sokratejskie pytania. Eseje wybrane, przeł. P. Maciejko, Warszawa 1998, s. 106.

Por. L. Strauss, Thoughts on Machiavelli, Chicago-London 1958, s. 9. 
też wyrafinowanego samorozumienia doniosłych konsekwencji przypisanego mu projektu nowoczesności. Wrażenie czytelnika może zostać potwierdzone przez lekturę listu do Erica Voegelina z 29 kwietnia 1953 r., w którym autor Natural Right and History stwierdza wprost (zapewne ku konsternacji adresata, odnosząc się do powstającego wówczas tekstu Thoughts on Machiavelli): „zacząłem pisać lentissime książeczkę o Machiavellim. Nie mogę się powstrzymać od miłości do niego - pomimo jego błędów"

Postać Machiavellego nie skupiła wszakże uwagi Straussa od samego początku - podjęte przez niego w latach 30. przedsięwzięcie opisania źródeł nowoczesnego myślenia o polityce (w świetle rozważań problemu teologiczno-politycznego, tj. napięcia pomiędzy konstytutywnym dla trwania wspólnoty politycznej sposobem życia opartym na podporządkowaniu wobec wyższego autorytetu z jednej, a opartym na swobodnym dociekaniu prawdy sposobem życia filozofa z drugiej strony) pierwotnie zakończyło się egzegezą dzieła Hobbesa. Uznawał wówczas, że „filozofia polityczna Thomasa Hobbesa stanowi pierwszą osobliwie nowoczesną próbę udzielenia koherentnej i wyczerpującej odpowiedzi na pytanie o słuszne życie człowieka, będące jednocześnie pytaniem o słuszny ład społeczeństwa [...] nikt z poprzedników Hobbesa nie próbował takiego definitywnego zerwania $\mathrm{z}$ tradycją $\mathrm{w}$ całej rozciągłości tejże, wynikającego $\mathrm{z}$ nowoczesnej odpowiedzi na pytanie o słuszne życie człowieka. Hobbes był pierwszym, który poczuł konieczność szukania - i udało mu się znaleźć - nuova scienza człowieka i Państwa. Na tej nowej doktrynie oparto - wyraźnie bądź po cichu - całą późniejszą myśl moralną i polityczną" ". Takie postawienie sprawy Strauss potraktował potem

Faith and Political Philosophy: The Correspondence Between Leo Strauss and Eric Voegelin, 1934 1964, przekład i red. P. Emberley, B. Cooper, Columbia-London 2004, s. 98 . W ujęciu Ernesta Fortina, ,jakkolwiek miałby słabość do starożytnych, Strauss nigdy nie przestał fascynować się nowoczesnymi i podziwiać ich za ich oryginalność, wdzięk i subtelność ich pism [...] to niezwykle przychylne usposobienie jaskrawo kontrastuje ze stanowiskiem Voegelina, który nienawidzi nowoczesnych i ma trudność ze znalezieniem pojedynczej ratującej ich cechy" (Straussian Reflections on the Strauss-Voegelin Correspondence, [w:] tegoż, Classical Christianity and the Political Order: Reflections on the Theologico-Political Problem, LanhamBoulder-New York-London 1996, s. 334).

L. Strauss, The Political Philosophy of Hobbes: Its Basis and Genesis, przeł. E. M. Sinclar, Chicago 1963, s. 1. Praca ta ukończona została pierwotnie w języku niemieckim w r. 1936, jednak nie mogła zostać opublikowana w Niemczech (stało się dopiero w 1965 r. - z tamtego czasu pochodzi fragment przedmowy wskazujący wagę „problemu teologiczno-politycznego"). Właściwie od razu powstał przekład na język angielski - i stało się to pod okiem Straussa, wprowadzającego pewne poprawki, tak, iż ta wersja może być summa summarum uznana za bardziej odpowiednią (por. D. Stauffer, Reopening the Quarrel between the Ancients and the Moderns: Leo Strauss's Critique of Hobbes „New Political Science”, „The American Political Science Review", vol. 101, nr 2, maj 2007, przyp. 2, s. 224). Zob. również H. Meier, Vorwort des Herausgebers, [w:] Hobbes' politische Wissenschaft und zugehörige Schriften - Briefe, red. H. Meier, W. Meier, Stuttgart-Weimar 2008, s. VII i n. 
jako błędne, czy w każdym razie niewystarczające ${ }^{5}$.Jednak to właśnie książka o Hobbesie, w przeciwieństwie do wielu późniejszych wystąpień tego autora - uwikłanych w przedstawienie ezoterycznego wymiaru egzegezy dorobku innych myślicieli i zarazem przyjmujących charakterystyczną retorykę obrony tradycji filozofii Sokratejskiej - cieszy się dość jednoznacznym, niesłabnącym uznaniem pozostałych badaczy myśli politycznej ${ }^{6}$. Strauss poświęca większą część swoich rozważań na wydobycie i opisanie „prawdziwej podstawy" nauki Hobbesowskiej, stanowiącej wyraz pozafilozoficznej motywacji twórcy Lewiatana i zawierającej się w jego „szczególnym nastawieniu moralnym". Owo nastawienie pozostaje czymś pierwotnym i niezależnym wobec deklarowanego zwrotu w kierunku metody naukowej, rozwijanej przez adeptów nowoczesnego przyrodoznawstwa ${ }^{7}$. Istotą rzeczy wydaje się odrzucenie próżności lub pretensji do arystokratycznej cnoty. Osąd porządku politycznego w kategoriach prawno-naturalnej hierarchii celów musi ustąpić miejsca ocenie niejako oddolnej; prawo naturalne (bądź raczej: uprawnienie przyrodzone ujęte jako poprzedzające podstawy ładu normatywnego) wynika z rozpoznania elementarnych pragnień czy dążeń, jakimi faktycznie powodują się ludzie w swej masie (redukowalnych do chęci samozachowania "tu i teraz”). Nacisk na „absolutnie uzasadniane subiektywne roszczenie" (right) zastępuje podkreślanie prawa przedmiotowego (law), wiązanego dotychczas z pojęciami „cnoty” czy „powinności”, . Założonym celem moralnym jest wieczny pokój oświeconych jednostek. Tym samym - powiada (w późniejszym tekście) Strauss - to „nie blask chwały - czy duma - lecz strach przed śmiercią stoi u kołyski społeczeństwa obywatelskiego: to nie bohaterowie dopuszczający się bratobójstwa, lecz nagie, drżące, biedne diabły są założycielami cywilizacji"”.

\footnotetext{
W amerykańskiej przedmowie z 1951 r. pisze wprost: „Hobbes wydawał mi się twórcą nowoczesnej filozofii politycznej. Był to błąd: nie Hobbes, a Machiavelli zasługuje na ten zaszczyt. Wciąż jednak wolę ten łatwo dający się poprawić błąd, lub raczej jego charakterystyczne przesłanki, od szerzej akceptowanych poglądów, którym zmuszony jestem się przeciwstawiać i które są mniej łatwe do poprawienia" (L. Strauss, The Political Philosophy..., s. xv). Por. L. Strauss, Trzy fale..., s. III.

6 Por. D. Stauffer, Reopening the Quarrel..., s. 225. Można zauważyć, że mniej więcej w tym samym czasie swoje interpretacje dzieła Hobbesa ogłosiło dwóch innych niezwykle znaczących (i kojarzonych z różnymi nurtami myślenia konserwatywnego) teoretyków nowoczesności: Michael Oakeshott i Carl Schmitt. Zob. R. Ömür Birler, The Leviathan and the Contours of Conservative Imagination: The Role of Thomas Hobbes in the Works of Schmitt, Strauss and Oakeshott, [http://www.cpsa-acsp.ca/papers-2004/Birler.pdf; dostęp: 12.12.2009].

Por. L. Strauss, The Political Philosophy..., s. 129.

Por. tamże, s. viii.

L. Strauss, Czym jest filozofia..., s. 99.
} 
Punkt ciężkości dociekań Straussa znajduje się jednak przy ukazaniu sposobu zerwania z tradycją filozofii politycznej. W myśl tej interpretacji, Hobbes od początku kieruje się przekonaniem, że o ile należy przyjąć cel powzięty przez dawnych myślicieli (dotyczący propozycji rozumnego ładu), o tyle tradycyjne nauczanie, rozwijane osobliwie w pismach następców Arystotelesa, skazane jest na porażkę w osiągnięciu tegoż celu. Pozostającego na poziomie opinii - i tym samym przydającego wyrazom namiętności obecnym w mowie zwykłych ludzi miano cnót - Arystotelesa przeciwstawia się Platonowi, którego wysiłek osiągnięcia naukowej precyzji staje się wzorem dla autora Lewiatana. ${ }^{10}$ Problem dotyczyłby zatem perspektywy, z jakiej Hobbes postrzega różnicę między Platonem i Arystotelesem. Zdaniem Straussa, jest to ujęcie karykaturalne i błędne, nieradzące sobie z rzeczywistą treścią stanowiska Platońskiego, któremu przypisuje się punkt wyjścia w postaci precyzyjnych idei, nie zaś niejasnych „słów”. „Najważniejszy aspekt nieporozumienia u Hobbesa [...] stanowi pogląd, iż Platon, zaczynając od «idei», odwraca się od opinii obecnych w codziennej mowie, podczas gdy chodzi mu o wnikliwe przebadanie utrwalonych przekonań i przyjętych opinii - takich, jakimi ujawniają się w dyskusji" ".1 . Strauss - o czym należy koniecznie pamiętać - nie czyta Platona „po chrześcijańsku”; wizja transcendentnego dobra („całkowicie wolnego od zła”) zamyka się w rozmowie z „młodymi”, pragnącymi żyć wedle cnoty; ,idei” nie należy rozumieć poza kontekstem codziennej mowy, jako pewnego wyrażenia aspiracji czy przekonan ${ }^{12}$. Z kolei nie można zaprzeczyć pewnemu podobieństwu podejścia Hobbesa i Platona nade wszystko w samej próbie znalezienia racjonalnego ideału wyrastającego ponad opinie zbudowane na uczuciach, które kształtują codzienny świat polityki. Jest to wszakże pozór zgodności. Pójście w tym kierunku (bądź przywołanie w duchu platońskim nauki Euklidesa) jedynie „ukrywa najgłębszą antytezę wobec Platona, jaką można sobie wyobrazić" ${ }^{13}$. Starożytny filozof nie pragnął zastąpienia perspektywy właściwej dla obywatela perspektywą właściwą dla nielicznych zdolnych poświęcić się czystej nauce. Poniesiony przez swoje „szczególne nastawienie moralne” Hobbes zmierza do wyznaczenia norm mających zastosowanie zawsze i wszędzie, wobec wszystkich. Jego stanowisko - w przeciwieństwie do zajmowanego przez klasyków - opiera się na próbie odseparowania nauki o polityce od wypowiedzi właściwych dla dyskursu politycznego.

Por. L. Strauss, The Political Philosophy..., s. 139-140.

D. Stauffer, Reopening the Quarrel..., s. 228.

Por. L. Strauss, The Political Philosophy..., s. 144 i n.

Tamże, s. 150 . 
Oznacza to wejście na ścieżkę wiodącą do „fatalnych” konsekwencji ${ }^{14}$, w ramach której refleksja filozoficzno-polityczna nie służy już wskazaniu (prawnonaturalnych) ograniczeń kształtowania (czy projektowania) polityki, lecz - przeciwnie - uczynieniu życia politycznego bardziej racjonalnym, na podstawie reguł nieskalanych przez język używany w nim na co dzień. Czyli: „Strauss wskazuje, iż porażka Hobbesa w zrozumieniu klasycznych myślicieli polega częściowo na niepowodzeniu w zadaniu fundamentalnego pytania o to, co uważali oni za prawdziwe cele i charakter filozofii politycznej" ${ }^{\prime 5}$. Czym innym jest rozjaśnienie opinii, czym innym - ich zamiana. Wolicjonalny projekt takiego uniwersalnego przekształcenia skazany jest, ponadto, na konfrontację z filozoficznie pomyślanym kontrprojektem. W ten sposób Hobbesowska wizja człowieka uruchamia niejako ciąg odpowiedzi pogłębiających nowoczesne myślenie w ramach kolejnych dwóch „fal nowoczesności”. „I tak - powiada Strauss - jak lekceważenie mowy prowadzi ostatecznie do relatywistycznego sceptycyzmu, tak też zanegowanie odwagi prowadzi do kontrowersyjnej postawy odwagi, która wyostrza się coraz bardziej na drodze od Rousseau przez Hegla do Nietzschego, a kończy się ponownym wchłonięciem mądrości przez odwagę, poglądem, że ideał nie stanowi przedmiotu mądrości, lecz ryzykowne przedsięwzięcie woli"16. Począwszy od zadeklarowania w teorii prymatu jednostkowych uprawnień, myśl nowoczesna ujawnia i ekspanduje swój dogmatyczny charakter.

Ten wcześnie wypracowany obraz spuścizny Hobbesa - wzmocniony przez odniesienie do dzieła Machiavellego - powraca w ramach interpretacji dziejów prawa naturalnego w sławnym „akcie założycielskim” szkoły Straussowskiej - Natural Right and History. Thomas Hobbes - określony tam jako „pierwszy plebejski filozof” - miał być tym, który zdołał wyciągnąć wnioski z intelektualnych przemian, jakie musiały nastąpić w obliczu ekspansji nieteleologicznych nauk przyrodniczych. Między nim oraz (znacznie rozważniejszym w swych sformułowaniach) Lockiem z jednej, a tomistą Richardem Hookerem z drugiej strony, istnieje przepaść spowodowana utratą czy też rezygnacją z fundamentalnych przesłanek, właściwych dla refleksji prawnonaturalnej zainspirowanej przez klasyków ${ }^{17}$. Z tego punktu widzenia, istotą nowego ujęcia byłaby próba połączenia dwóch tradycji: „idealistycznej”, reprezentowanej przez klasyków w ich dążeniu do przedstawienia wizji najlepszego (zgodnego z naturą) ustroju, której można zatem przypisać troskę o dobro wspólne, oraz „antyidealistycznej”, dającej się skojarzyć z epikure-

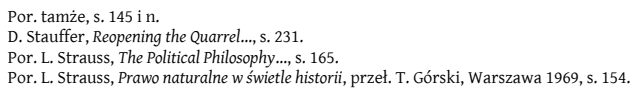


izmem (poglądem konwencjonalistycznym, tzn. rezygnującym z szerszego namysłu filozoficzno-politycznego - gdyż każdy ustrój jest faktycznie contra naturam - na rzecz rozpatrywania dobra jednostkowego czy prywatnego), na którą Hobbes, skłonny upodobnić własne dzieło raczej do Państwa Platona niż do 0 naturze rzeczy Lukrecjusza, nie powołuje się wprost. Chce on podtrzymać przekonanie na temat funkcji czy zakresu refleksji „idealistycznej”, równocześnie jednak przeczy politycznej czy społecznej naturze człowieka. Tym samym, ,hedonistycznej tradycji usiłuje przekazać ducha idealizmu politycznego. W ten sposób stał się twórcą hedonizmu politycznego, doktryny, która zrewolucjonizowała wszędzie życie ludzkie na niespotykaną dotąd skalę"18, która to doktryna otwiera zarazem furtkę dla politycznego ateizmu, niewiary w to, iż bycie obywatelem łączy się z potrzebą odniesienia do Boga; „królestwo ciemności” można i należy obalić ${ }^{19}$.

18 Tamże, s. 157. Strauss poświęca nieco miejsca na porównanie doktryny Hobbesa oraz „apolitycznego hedonizmu" Epikura. Życie zgodne z naturą, które dla klasyków wymaga kontekstu zdrowej wspólnoty politycznej, z punktu widzenia konwencjonalisty oznacza żywot „w pełni rozwinięty” (filozofa, a może tyrana). „Hobbes przez swoją koncepcję stanu natury odrzuca tak pogląd klasyków, jak i konwencjonalistów, ponieważ zaprzecza istnieniu naturalnego celu, czyli summum bonum [...] zdaniem Hobbesa nie ma żadnego napięcia między społeczeństwem cywilnym a naturą, podczas gdy zdaniem konwencjonalistów pomiędzy społeczeństwem cywilnym a naturą istnieje napięcie. Stąd według konwencjonalistów życie według natury stoi wyżej od życia w cywilnym społeczeństwie, natomiast według Hobbesa jest odwrotnie. Dodajmy, że konwencjonalizm wcale nie musi być egalitarystyczny, podczas gdy myśl Hobbesa z konieczności implikuje egalitaryzm" (Prawo naturalne..., przypis 23, s. 171). „Hobbes mógł zgodzić się z Epikurem w następujących punktach: dobro jest zasadniczo identyczne z przyjemnym; cnota nie stanowi wartości sama przez się, ale ze względu na osiągnięcie przyjemności lub uniknięcie cierpienia; pragnienie honoru czy sławy są zupełnie próżne, to znaczy zmysłowe przyjemności jako takie są bardziej pożądane aniżeli honor czy sława”. Zarazem: „Hobbes musiał przeciwstawić się Epikurowi w dwu zasadniczych punktach, aby uczynić możliwym polityczny hedonizm. Przede wszystkim musiał odrzucić zaprzeczenie przez Epikura stanu natury w ścisłym znaczeniu tego słowa, to znaczy życia przedpolitycznego, w którym człowiek korzysta z praw naturalnych, ponieważ Hobbes zgadzał się z idealistyczną tradycją co do tego, że prerogatywy społeczeństwa cywilnego łączą się ściśle z istnieniem prawa naturalnego”. Po drugie, „,nie mógł przyjąć implikacji wynikającej z wprowadzenia przez Epikura różnicy pomiędzy koniecznymi a niekoniecznymi pragnieniami naturalnymi" [...] (tamże, s. 174). Można powiedzieć, iż nauczanie epikurejskie jawiło się Hobbesowi jako za bardzo uwikłane w klasyczne rozumienie utopii, w duchu której jednostkom stawia się zbyt wysokie wymagania; wszak nie każdy odnajdzie w sobie pragnienie bycia ascetycznym filozofem. W konsekwencji nowego ujęcia, „dobre życie” nie mogło mieć pretensji do doskonałości, mogło natomiast - do wygody. Nie jest zadaniem władcy uszlachetniać ludzi; ma on za to - dzięki wykorzystaniu zdobyczy nauki, umożliwiających szeroki dostęp do rzeczy przyjemnych (bez pomocy technologii łatwo otrzymujemy jedynie to, co konieczne) - dążyć do obfitego zaopatrzenia obywateli (por. tamże, s. 175). Zob. również tamże, s. 255.

Por. M. Lilla, Bezsilny Bóg: religia, polityka i nowoczesny Zachód, przeł. J. Mikos, Warszawa 2009, s. 81-98. Zob. również L. Strauss, Die Religionskritik des Hobbes. Ein Beitrag zum Verständnis der Afklärung, [w:] tegoż, Hobbes' politische Wissenschaft..., s. 263-369. 
Zdaniem Straussa, sposób, w jaki Hobbes łączy podejście „idealistyczne" z materialistycznie (za epikureizmem) ugruntowanymi przesłankami, nie stanowi „eklektycznego kompromisu”, lecz syntezę; wprowadza zatem świadomie bądź nie - nową jakość ${ }^{20}$. W tym miejscu pojawia się - bliski Kartezjuszowi - postulat wypracowania metody, która w imię urzeczywistnienia mądrości „zadośćuczyniłaby prawdzie zawartej w sceptycyzmie”; tradycyjnie uprawianej filozofii, z jej dogmatycznym zacięciem, towarzyszyło bowiem od zawsze krańcowe wątpienie; zatem: „to, co przetrwa napór skrajnego sceptycyzmu, będzie absolutnie bezpieczną podstawą mądrości" ${ }^{21}$. Podążając tą ścieżką rozumowania, docieramy do postulatu stworzenia przez naukę „sztucznej wyspy”. Wszakże, „ogólnie mówiąc, mamy absolutnie pewną, czyli naukową wiedzę o tych tylko zagadnieniach, których sami jesteśmy autorami, to znaczy których konstrukcja zależy od naszej woli" ${ }^{22}$. Nauka o przyrodzie, choć jako taka nie może wyjść poza stadium umocowania na poziomie hipotez, wystarczy dla zawojowania natury. Brak tutaj, obecnego jeszcze w dawnym nominalizmie ${ }^{23}$, przeświadczenia o naturalnej harmonii wszechświata i umysłu człowieka. Jest to cena nowoczesnego projektu, gdyż „człowiek może być władcą tylko wówczas, jeżeli nie ma w kosmosie żadnego oparcia dla swego człowieczeństwa. Może być władcą tylko dlatego, ponieważ jest całkowicie obcy w tym wszechświecie. Może być władcą, ponieważ jest zmuszony do tego" ${ }^{24}$. Zainicjowane przez Hobbesa „świadome konstrukcje” - pojmowane jako jedyny gwarantowany sposób uzyskania mądrości - oznaczają tym samym konieczne zacieśnienie horyzontów myślowych człowieka, postawionego w samotnym cierpieniu na-

${ }^{20}$ Jak wskazuje Victor Gourevitch, podporządkowująca naturę synteza Hobbesowska nie może być w żadnym razie traktowana przez Straussa jako rozwiązanie alternatywne względem propozycji formułowanych przez klasycznych zwolenników prawa naturalnego z jednej, konwencjonalistów z drugiej strony; sam autor nie rozstrzyga tej kwestii (zob. Victor Gourevitch, The Problem of Natural Right and the Fundamental Alternatives in 'Natural Right and History', [w:] The Crisis of Liberal Democracy: A Straussian Perspective, red. K. L. Deutsch, W. Soffer, New York 1987, s. 38). Por. w odniesieniu do Machiavellego, L. Strauss, Machiavelli and Classical Literature, „Review of National Literatures” 1970, nr 1, s. 10.

L. Strauss, Prawo naturalne..., s. 159.

Tamże, s. 160.

Jest rzeczą skądinąd interesującą, że termin „nominalizm” (zastosowany jednorazowo przy omawianiu doktryny Hobbesa) został uwzględniony jako jedyne pojęcie w indeksie Natural Right and History, który poza tym odnosi się tylko do nazwisk (rzecz pominięta w polskim przekładzie).

L. Strauss, Prawo naturalne... , s. 162. Za najlepszą ilustrację tego nowoczesnego stanu ducha może posłużyć sławny zwrot Blaise’a Pascala: „wiekuista cisza tych nieskończonych przestrzeni przeraża mnie" (Myśli, przeł. T. Żeleński-Boy, Warszawa 2002, s. 62). Nadto, por. K. Löwith, Nature, History, and Existentialism, [w:] tegoż, Nature, History, and Existentialism and Other Essays in Philosophy of History, Evanston IL 1966, s. 17-29. 
przeciw tego, co niepojęte. Wieczność oddala się i zanika. Kiedy zaś do głosu - w ramach „drugiej fali nowoczesności” - dochodzą siły „Historii”, jakakolwiek „najwyższa zasada” konstytutywna dla państwa czy społeczeństwa może być odniesiona jedynie do zmiennych kolei naszych wspólnych losów ${ }^{25}$.

Hobbes okazuje się budowniczym zapełniającym przestrzenie nowego lądu, przeznaczonego do swobodnej, ludzkiej kreacji. Odkrycie tegoż lądu czy „kontynentu” należy do „założyciela nowoczesnej filozofii politycznej”, w pełni odpowiedzialnego za porzucenie perspektywy klasyków, a mianowicie do Machiavellego. Zostaje on przedstawiony jako twórca nowej filozofii zmierzającej do „zawojowania natury” - wypracowania warunków do urzeczywistnienia „radykalnej wolności” - który „niszczy naturalną podstawę rozróżnienia między filozofami i niefilozofami"; wszakże, o ile to konieczność warunkuje doskonałość, o tyle „owo przejście albo skok z królestwa konieczności do królestwa wolności będzie śmiercią w niesławie samej możliwości ludzkiej doskonałości” ${ }^{26}$. Z jednej strony „Machiavelli studiował zagadnienia polityczne, powodując się troską o dobro publiczne", był więc „filozofem o dużym poczuciu obywatelskim" ${ }^{27}$, kontynuatorem „idealistycznej" tradycji myślenia o polityce; z drugiej wszakże - mimo podziwu dla Rzymu i klasyków, „odrzucił on klasyczną filozofię polityczną, a tym samym całą tradycję filozofii politycznej w pełnym tego słowa znaczeniu, jako bezużyteczną, gdyż klasyczna filozofia polityczna kierowała się tym, jak człowiek powinien żyć” - tymczasem, wedle Machiavellego, „na pytanie o sprawiedliwy porządek społeczny można dać odpowiedź tylko w oparciu o to, jak faktycznie ludzie żyją" ${ }^{28}$. Szlachetna refleksja zakorzeniona w tradycji sokratejskiej zyskuje zupełnie nowy wyraz. Problemem nie jest wszakże preparowanie fałszywej doktryny sięgającej poza to, o czym wiedzieli klasycy; rzecz dotyczy raczej sposobu posłużenia się ich wiedzą. Strauss posuwa się do konstatacji, iż „można z pewnością powiedzieć, że nie ma takiego moralnego czy politycznego zjawiska, które znał Machiavelli lub którego odkrycie przyniosło mu sławę, a którego przed nim nie znałby świetnie Ksenofont, nie wspo-

\footnotetext{
Por. L. Strauss, Prawo naturalne..., s. 163.

L. Strauss, Thoughts on Machiavelli..., s. 298. Por. N. Machiavelli, Rozważania nad pierwszym dziesięcioksięgiem historii Rzymu Liwiusza, przeł. K. Żaboklicki, [w:] tegoż, Wybór pism, Warszawa 1972, s. 543.

28 Tamże, s. 165. Machiavelli zdaje się walczyć o restytucję porządku politycznego wypracowanego w świecie odwołującym się do myśli klasyków. Jego przesłanie zawierałoby się tedy w twierdzeniu, że „polityka i instytucje klasycznej starożytności mogą i powinny być naśladowane przez człowieka nowoczesnego: zamysł Discorsi jako całości zawiera się w uwolnieniu ludzi od błędnego przekonania, że polityka i instytucje klasycznej starożytności nie mogą i nie powinny być naśladowane przez człowieka nowoczesnego" (L. Strauss, Walker's Machiavelli, „Review of Metaphysics” 1952/1953, nr 6, s. 441).
}

26 
minając już o Platonie czy Arystotelesie" ${ }^{29}$. Jak więc zidentyfikować wskazany problem? Po pierwsze, Machiavelli, jakkolwiek - co zwraca uwagę Straussa - nie mówi o wszystkim wprost (np. wychwalając religię pogańskiego Rzymu, zdaje się potępiać Rzym sobie współczesny ${ }^{30}$ ), to jednak - jako autor Księcia - pisze niejako skrypt dla badacza dziejów, będącego politycznym gangsterem; stawia siebie w pozycji proroka przyszłych działań, opartych na formule jego własnej nauki; wyrusza na „wojnę duchową", w której stawką jest kontrola myśli kształtujących losy (postchrześcijańskiego) Zachodu ${ }^{31^{2}}$. Czy jest więc tak, jak powiada Paweł Śpiewak, że „błędem Machiavellego nie było jego rzekomo cyniczne nauczanie, ale to, że nauczał tyrańskich umiejętności w sposób nazbyt jawny [...] autor Księcia odrywa mądrość od umiarkowania i niczym przed publicznością nie maskuje swych obrazoburczych pomysłów" ${ }^{\text {,32 }}$ - zatem: mielibyśmy do czynienia z filozofem wyrażającym prawdziwą naukę w nieodpowiedniej formie? Czy wina Machiavellego zamyka się w zarzucie o nieodpowiedzialną mowę, o porzucenie nie tyle prawnonaturalnych treści nadających się do wyeksponowania w dziele klasyków, ile „retoryki Sokratejskiej”, traktowanej jako środek udaremniający próby „tyranizowania myśli" ${ }^{33}$ ?

Jednakże, po drugie, można wskazywać, iż Machiavelli posługuje się dziedzictwem starożytnych w sposób niejednoznaczny i wybiórczy. Jednym z jego ulubionych autorów jest Ksenofont. W przeciwieństwie do niego, w najsłynniejszej swojej książce zdradza całkowitą, rozmyślną obojętność wobec tradycyjnego rozróżnienia króla i tyrana. Książę jawi się jako zwierciadło władcy; nie odwołuje się jednak w zasadzie do popularnej w jego czasach formy literackiej, lecz do klasycznego - dziś niedocenianego - utworu Ksenofonta Wychowanie Cyrusa. „Można powiedzieć, iż Wychowanie Cyrusa poświęcone jest doskonałemu królowi w przeciwieństwie do doskonałego tyra-

29 L. Strauss, Machiavelli, przeł. A. Lipszyc, „Przegląd Polityczny” 2008, nr 87, s. 133.

${ }^{30}$ Zob. L. Strauss, Machiavelli and Classical..., s. 17. Wyłania się stąd teologiczno-polityczny aspekt myśli Machiavellego, stanowiący w istocie punkt ciężkości egzegezy Straussowskiej. „Tradycja, którą Machiavelli, mimo radykalnego jej przekształcania, kontynuuje [...] jest tą, którą możemy ciągle, z wybaczalną ignorancją, nazywać tradycją awerroistyczną" (L. Strauss, „Hieron” Ksenofonta, [w:] tegoż, O tyranii, przeł. P. Armada, A. Górnisiewicz, Kraków 2009, s. 173). Por. tegoż, Thoughts on Machiavelli..., s. 202-203. Zdaniem Straussa, odrzucenie prawa naturalnego i tym samym klasycznego powiązania życia politycznego z kwestią „ostatecznego celu” człowieka - czyli narodziny podejścia stanowiącego punkt wyjścia nowoczesności - znajduje swój wczesny wyraz w spuściźnie awerroistycznego myśliciela chrześcijańskiego, Marsyliusza z Padwy. Zob. zwł. L. Strauss, Marsilius of Padua, [w:] Liberalism Ancient and Modern, Ithaca-London 1989, s. 200-201.

Por. L. Strauss, Czym jest filozofia..., s. 96-97.

32 P. Śpiewak, Filozof i polityka. Uwagi o myśli Leo Straussa, [w:] Dziedzictwo greckie we wspótczesnej filozofii politycznej, red. P. Kłoczowski, Kraków 2004, s. 79.

33 Por. L. Strauss, O tyranii..., zwłaszcza s. 26. 
na, gdy tymczasem Książę wyróżnia się rozmyślnym lekceważeniem różnicy między królem i tyranem. Istnieje jedno tylko wcześniejsze dzieło na temat tyranii, do którego odwołuje się wprost Machiavelli: Hieron Ksenofonta (w swych Rozważaniach nad pierwszym dziesięcioksięgiem historii Rzymu Tytusa Liwiusza). Analiza Hierona prowadzi do wniosku, że nauczanie w tym dialogu zbliża się do nauk Księcia tak bardzo, jak tylko to możliwe w przypadku któregokolwiek z sokratyków. Przez skonfrontowanie nauk Księcia z tymi, które oddaje Hieron, można najwyraźniej uchwycić najbardziej subtelną i w istocie rozstrzygającą różnicę pomiędzy Sokratejskimi a Makiawelowskimi naukami politycznymi. Jeśli prawdą jest, że cała przednowoczesna nauka o polityce spoczywa na fundamentach położonych przez Sokratesa, podczas gdy cała swoiście nowoczesna nauka o polityce spoczywa na fundamentach położonych przez Machiavellego, to możemy również powiedzieć, iż przednowoczesne i nowoczesne nauki polityczne zetknęły się ze sobą najbliżej w punkcie wyznaczonym przez Hierona" ${ }^{\text {,34 }}$. Czym jest ten punkt? Dlaczego Strauss utrzymuje, że Machiavelli znakomicie zrozumiał „lekcję Ksenofonta”, a rów-

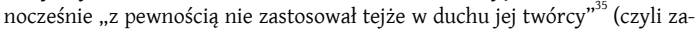
pewne w duchu tradycji sokratejskiej)? Odpowiedź zdaje się znów dotyczyć zagadnienia natury retorycznej. Otóż klasyczny doradca tyranów (poeta Symonides, uczyniony bohaterem Hierona) zdradza swą niegodziwość nie w mowie, lecz poprzez milczenie. Nie sławi on reguł godzących w moralność, nie deklaruje braku lęku przed diabłem. Ujawnia swój stosunek do zasad moralnych wtedy, gdy rezygnuje z eksponowania ich; politykę pojmuje przez czyn, nie słowo. Można więc znowu sądzić, że nowoczesne nauki polityczne po Machiavellim zapoznają kluczowy dla - odczytywanej przez Straussa - retoryki sokratejskiej związek mądrości i umiarkowania.

Zarazem, twórca koncepcji „trzech fal nowoczesności” podsuwa nieco inne sformułowanie tej kwestii. Według niego, „wszechświat moralny Ksenofonta ma dwa bieguny: jeden wskazywany przez wielkiego człowieka politycznego, powiedzmy, Cyrusa, drugi zaś - wskazywany przez uczczonego mistrza Ksenofonta - Sokratesa. Jednak we wszechświecie moralnym Machiavellego nie ma miejsca dla Sokratesa" ${ }^{36}$. Filozofia zostaje zdegradowana. Skuteczność polityka czy prawodawcy nie odpowiada stanowi życia kontemplacyjnego, z jakim styka się Machiavelli. Osiągnięcie pożądanych rezultatów w polityce wymaga raczej posłużenia się praktycznymi rezultatami refleksji filozoficznej. Szukający mądrości staje się naukowcem; pożyteczny efekt jego

Tamże, s. 24.

Tamże, s. 52 .

L. Strauss, Machiavelli and Classical..., s. 13. 
pracy - rękojmią dobrostanu. Kluczowe staje się zdobycie poczucia pewności w takim zakresie spraw, jaki poddaje się kontroli. „Obrazoburcze pomysły” Machiavellego dotyczą więc „obniżenia standardów działań społecznych”, co miałoby „prowadzić do zwiększenia możliwości zrealizowania schematu, który jest konstruowany na ich podstawie. W ten sposób znika zależność od przypadku; przypadek zostaje opanowany" ${ }^{37}$. Innymi słowy: zerwanie z tradycją klasyczną stanowić miało świadomy ruch inicjujący projekt oświecenia, dla którego - obok orientacji na „rzeczywiste” standardy ludzkiego postępowania - charakterystyczna jest również sugestia co do możliwości „zawojowania natury”, lub że kierujący naszymi losami przypadek (fortuna) powinien zostać poddany kontroli ${ }^{38}$. W tym miejscu można przywołać sformułowane wcześniej przez Straussa rozróżnienie między prawomocnym utopizmem klasyków oraz utopizmem nowoczesnym: „żądłem moralnym” i „inżynierią społeczną" ${ }^{39}$. Zamiast wskazywać ludziom wzory, do których i tak się nie dostosują, skupiamy uwagę na rozeznaniu ich realnych dążeń i pokierowaniu nimi. Pojęcie „dobra wspólnego” zostaje zatem utożsamione z rzeczywistymi celami różnych społeczeństw (takimi jak niezależność czy dostatek), a „cnotę” rozumie się jako „zbiór nawyków” potrzebnych do osiągnięcia danego celu. Owych dóbr i cnót nie otrzymuje człowiek „z góry” natura nie jest dostarczycielem wskazówek na temat kierunku urzeczywistnienia jego potencjalnej doskonałości; jego sytuację można natomiast zobrazować w ten sposób, iż będąc w pełni plastycznym tworzywem, niejako wykształca się sam. Jedyną rozsądną odpowiedzią na ludzkie pragnienie sprawiedliwości okaże się - w miejsce nieskutecznego kaznodziejstwa, uprawianego dotychczas przez reprezentantów vita contemplativa - stworzenie takich instytucji, które uczyniłyby niesprawiedliwe postępowanie - postępowaniem nieopłacalnym. Podstawą tak pojętej kreacji budzącego zaufanie ładu instytucjonalnego musi być należyte rozpoznanie przypadków skrajnych jako lepiej (od sytuacji powszednich) unaoczniających przyczyny sprawcze ludzkich zachowan ${ }^{40}$. „W nauczaniu Machiavellego - stwierdza

\footnotetext{
L. Strauss, Czym jest filozofia..., s. 92.

Por. L. Strauss, 0 tyranii..., przyp. 5, s. 101. Powrót do „sposobów działania i porządków” starożytnego Rzymu jest o tyle kłopotliwy, o ile ich faktyczne źródło mieści się w domenie reakcji na nieprzewidywalne ciągi przypadkowych wydarzeń. Ustrój rzymski stanowi ostatecznie dzieło przypadku; utrwalił się on dzięki poszanowaniu dokonań przodków. „To, co do tej pory było szczęśliwym zbiegiem okoliczności, a zatem czymś zasadniczo ułomnym, staje się od teraz - na nowym kontynencie odkrytym przez Machiavellego - celem racjonalnego pragnienia oraz działania” (L. Strauss, Machiavelli and Classical..., s. 22).

39 Zob. L. Strauss, Czego uczy nas teoria polityczna, przeł. M. Warchała, „Przegląd Polityczny” 2008 , nr 87, zwłaszcza s. 155.

Por.: L. Strauss, Czym jest filozofia..., s. 93-94; Prawo naturalne..., s. 165-166; Trzy fale..., s. V.
} 
Strauss - mamy pierwszy przykład schematu, który powtarzał się odtąd w niemal każdym pokoleniu. Nieustraszony myśliciel wydawał się odsłaniać otchłań, przed którą wzdragali się klasycy w swej szlachetnej prostocie" ${ }^{41}$. Tymczasem - jak to już zostało wskazane - nie mówi on niczego nowego, gdy idzie o obserwacje odnośnie do natury ludzkiej; horyzont myślowy nie został poszerzony, stało się coś przeciwnego, mianowicie - utracony został Sokratejski „biegun” filozofii politycznej.

Dlaczego - pyta Strauss - ulegliśmy złudzeniu? W tym miejscu wypada jedynie zasygnalizować, iż próba wytłumaczenia tego stanu rzeczy (tj. fałszywego, nowoczesnego przekonania o tym, że uczyniony został postęp w teoretycznym ujęciu spraw ludzkich) prowadzi do rozważań wokół problemu teologiczno-politycznego. Nowoczesność powstaje w reakcji na chrześcijańskie psucie perspektywy klasyków: wszak „do czasów Machiavellego klasyczna tradycja przeszła głębokie przemiany. Życie kontemplacyjne znalazło swój dom w klasztorach. Cnota moralna została przekształcona w chrześcijańską dobroczynność. W wyniku tego odpowiedzialność człowieka wobec innych ludzi nieskończenie się zmniejszyła" ${ }^{42}$. Pobożność czy pragnienie zbawienia nieśmiertelnej duszy wiodły do czynów nieznajdujących usprawiedliwienia w duchu sokratejskim. Nazbyt ambitny cel, z założenia obejmujący wszystkich, stanowił źródło krzywd, których można było uniknąć. „Antyteologiczny gniew” autora Księcia wyznacza moment narodzin lub raczej: zaprogramowania - perspektywy oświeceniowej.

Straussowski Hobbes nie czyni nic innego, jak tylko podąża wyznaczonym torem, w pewien sposób łagodząc podejście Machiavellego ${ }^{43}$. Wkład, jaki należy przypisać myślicielowi angielskiemu - widzącemu siebie w roli właściwego twórcy nowej nauki o polityce - dotyczyłby podjęcia „próby przywrócenia moralnych zasad polityki, czyli prawa naturalnego na płaszczyźnie

41

Tamże, s. 95. „Dla Straussa, chrześcijaństwo odgrywa kluczową rolę pośrednika. Nowoczesność nie jest dlań zsekularyzowanym chrześcijaństwem, raczej jest to odrzucenie chrześcijaństwa - tym samym jest ona wszak uwarunkowana przez owo odrzucenie" (N. Robertson, The Closing of the Early Modern Mind: Leo Strauss and Early Modern Political Thought, [http://www.mun.ca/ animus/1998vol3/roberts3.htm; dostęp: 12.12.2010], przypis 92, s. 19.

Trudność zawarta w tego rodzaju stwierdzeniu polega na tym, że w dziele Hobbesa próżno szukać bezpośrednich odwołań do prac Machiavellego. Straussowi chodzi raczej o ducha nowoczesnej filozofii politycznej, wynalezionego przez autora Księcia, a w którym odnajdują się tacy myśliciele, jak Hobbes czy Spinoza, bądź - innymi słowy - o zamknięcie późniejszej refleksji w ramach użycia „postmachiavellowskiego języka: właściwy ideał z konieczności zostaje urzeczywistniony; to, co idealne, z konieczności zbiega się z tym, co rzeczywiste. Ten sposób myślenia odniósł niebywały sukces; jeśli ktoś dzisiaj utrzymuje, że nie ma gwarancji urzeczywistnienia ideału, naraża się ma zarzut cynizmu" (L. Strauss, Machiavelli..., s. 125). 
«realizmu» Machiavellego" . By móc tego dokonać, był on zmuszony oddzielić refleksję prawno-naturalną od „idei doskonałości człowieka”: prawo naturalne ma sens, gdy nie określa się jego treści poprzez cel, ale - przez wskazanie na początki człowieczeństwa, czy też faktyczny charakter egzystencji. Substancja nowo podjętej refleksji nie sytuuje się na poziomie rozu$\mathrm{mu}$ (nie jest on rzeczywistym przewodnikiem na planie życia jednostki), lecz namiętności; ostatecznie nie chodzi o nic innego, jak tylko o strach przed śmiercią znienacka dopadającą człowieka. „Zasadniczy fakt moralny” utożsamia się z uprawnieniem; tym samym - „wszelkie obowiązki wypływają z podstawowego i niepozbywalnego prawa samozachowania" charakter jedynie warunkowy. Wziąwszy to pod uwagę, stajemy niechybnie wobec obrazu państwa niepowołanego do kształcenia cnoty obywatelskiej, postawionego za to na straży jednostkowego uprawnienia. Można więc uznać, iż ,jeśli liberalizmem nazwiemy tę polityczną doktrynę, która za zasadniczy fakt uważa prawa (w odróżnieniu od obowiązków) człowieka i która utożsamia funkcję państwa z ochroną czy strzeżeniem tych praw, to musimy przyznać, że twórcą liberalizmu był Hobbes" ${ }^{46}$.

Rewolucyjny potencjał samej idei prawa naturalnego ${ }^{47}$ zostaje raz na zawsze uwidoczniony w nowej doktrynie uprawnień przyrodzonych („prawa człowieka”, jak wskazywał Burke, łatwo sobie przyswoić ${ }^{48}$ ). Strauss wymownie podkreśla, że „skuteczność współczesnemu prawu naturalnemu zapewnia raczej oświecenie lub propaganda aniżeli odwoływanie się do zasad moralnych" ${ }^{49}$. Jest to zarazem podejście doktrynerskie, wyzbyte klasycznego dystansu czy zdrowej elastyczności, wynikające ze wskazanego wcześniej niezrozumienia istotnego celu filozofii politycznej. Jednakże kluczowe zagadnienie zdaje się sytuować znów w wymiarze teologiczno-politycznym. Skoro bowiem fundamentalne założenie myśli Hobbesowskiej stanowi pogląd na człowieka jako istotę kierującą się strachem przed gwałtowną śmiercią, to jak odnieść się do nader częstej sytuacji, gdy nie ów strach, tylko bojaźń w stosunku do Boga i piekła decydowałyby o ludzkim postępowaniu?

44. L. Strauss, Prawo naturalne..., s. 166.

${ }^{45}$ Tamże, s. 167. W konsekwencji należy przyjąć np. sąd mówiący o tym, iż postępowanie dezertera nie jest niesprawiedliwe, jeśli nie kieruje się on motywem zdrady, lecz po prostu boi się. W ujęciu Straussa, „przyznając to, Hobbes obalił moralną podstawę obrony narodu. Jedynym rozwiązaniem tej trudności w duchu filozofii politycznej Hobbesa byłby zakaz wojny lub ustanowienie państwa światowego" (tamże, s. 182).

46 Tamże, s. 168. Por. C. Schmitt, Lewiatan w teorii państwa Thomasa Hobbesa. Sens i niepowodzenie politycznego symbolu, przeł. M. Falkowski, Warszawa 2008, s. 71-74.

Por. L. Strauss, Prawo naturalne..., s. 89.

48 Zob. E. Burke, Thoughts on French Affairs etc, [http://ourcivilisation.com/smartboard/ shop/burkee/frnchaff/index.htm\#Russia; dostęp: 12.12.2010].

49 L. Strauss, Prawo naturalne..., s. 169. 
Rozwiązanie jest poniekąd proste i wprowadza ono „najważniejszą konsekwencję doktryny Hobbesa": świat musi zostać odczarowany. Ludzie będą bać się diabłów, duchów czy niewidzialnych mocy i to uczucie będzie w nich przeważać strach przed nagłym zgonem dopóty, dopóki ogół tego rodzaju złudzeń pozostaje przedmiotem ich wiary. Nowa „konstrukcja” zadziała wtedy, kiedy oświecone jednostki staną oko w oko z prawdziwą rzeczywistością. „Wynika z tego - powiada Strauss - że cały system Hobbesa wymaga dla swego funkcjonowania osłabienia czy raczej wyeliminowania strachu przed niewidzialnymi siłami. System taki wymaga radykalnej zmiany orientacji, jaką można przeprowadzić tylko przez odczarowanie świata, przez rozpowszechnienie naukowej wiedzy, czyli przez oświecenie mas. Doktryna Hobbesa jest pierwszą doktryną, która jawnie i niedwuznacznie wskazuje na całkowicie oświecone, tzn. areligijne czy ateistyczne społeczeństwo, jako rozwiązanie społecznego czy politycznego problemu" ${ }^{, 50}$. Autor Lewiatana okazuje się więc nie tyle oryginalnym filozofem programującym wielką przemianę perspektywy (jak Machiavelli), ile konsekwentnym rzecznikiem pomyślanego wcześniej oświecenia. Nowoczesna „filozofia" ulega polityzacji; zostaje przejęta przez opinię publiczną; staje się „,bronią i narzędziem”, ${ }^{, 51}$.

Przechodząc do omówienia pism Locke'a, Strauss będzie podkreślał jego ostrożność - „rodzaj szlachetnej obawy” piszącego ${ }^{52^{2}}$ - jest to wszakże asekuracja pozorna i niewystarczająca. Szczegółowa analiza myśli Locke'owskiej służy do wyeksponowania w niej prymatu uprawnień nad przedmiotowym prawem naturalnym, sprowadzonym do rzędu norm służących realizacji subiektywnego roszczenia ${ }^{53}$. Strauss sugeruje zastosowanie przez Locke'a języka Objawienia - czy raczej subtelnej gry między światopoglądem chrześcijańskim a zyskującym popularność deizmem - niby zasłony dymnej dla nowoczesnego projektu ekspansji społeczeństwa technologicznego, nie znoszącego ograniczających z góry nakazów ${ }^{54}$. „Przez budowanie cywilnego społeczeństwa na «niskiej, lecz solidnej podstawie» egoizmu czy niektórych «osobistych wad» osiągnie się o wiele większe «publiczne korzyści» aniżeli

50 Tamże, s. 183. Zob. także P. Sloterdijk, Pogarda mas. Szkic o walkach kulturowych we wspótczesnym społeczeństwie, przeł. B. Baran, Warszawa 2003, zwłaszcza s. 31-33; por. C. Schmitt, Lewiatan w teorii ..., zwłaszcza s. 54 i n.

Por. L. Strauss, Prawo naturalne..., s. 38.

Zob. tamże, s. 190-193.

Por. H. A. Rommen, The Natural Law. A Study in Legal and Social History and Philosophy, przeł. Th. R. Hanley, Indianapolis 1998, s. 79.

${ }^{54}$ „Prawo natury jest deklaracją woli Boga” (L. Strauss, Prawo naturalne..., s. 187) - czy zatem istnieje poza normą objawioną przez Boga, jako możliwy rezultat dociekań filozoficznych? Wydaje się, że jest to w oczach Straussa nowoczesna konstrukcja „propagandowa”, słabo przykrywająca rzeczywiste intencje Locke’a (por. tamże, s. 187 i n., zwłaszcza s. 195-199). 
przez bezskuteczne odwoływanie się do cnoty, która z natury jest «bezowocna»" ${ }^{55}$. Nowa propozycja sprowadza się w końcu do porzucenia obu wielkich tradycji: biblijnej i filozoficznej; nie równoważy ona, a umacnia zamysł patrzenia na człowieka jako na początek czy ośrodek tego, co moralnie istotne. Doktryna Locke'a - mimo zewnętrznego złagodzenia - zawiera w sobie podejście bardziej radykalne (w zestawieniu z tradycją refleksji prawnonaturalnej), niż to wypracowane u Hobbesa. „Według Locke’a człowiek, a nie natura, praca człowieka, a nie dar natury jest źródłem prawie wszystkich wartości: człowiek zawdzięcza prawie wszystkie wartości swoim własnym wysiłkom. Nie wdzięczność pełna rezygnacji i świadome posłuszeństwo czy naśladowanie natury, lecz pełne zaufanie do siebie i twórczość stały się odtąd znamionami ludzkiej szlachetności. Człowiek jest skutecznie wyzwolony z ograniczeń natury, a tym samym jednostka jest wolna od społecznych więzów poprzedzających wszelką zgodę czy umowę, w wyniku emancypacji produktywnego nabywania, które jest z konieczności, chociaż przypadkowo, korzystne i konsekwentnie może stać się najsilniejszą więzią społeczną: powściąganie pragnień jest zastąpione przez mechanizm, którego skutek jest humanitarny. Ta emancypacja urzeczywistnia się za pośrednictwem prototypu rzeczy konwencjonalnych, czyli pieniędzy" (których wartość nie wynika z natury rzeczy, lecz z umownego stanowiska ogółu ich użytkowników). Ostatecznie - według tego, jak Strauss interpretuje Locke'a - „świat, w którym zdaje się całkowicie panować twórczość człowieka, jest faktycznie światem, który zastąpił normę natury normą konwencji” ${ }^{56}$. Myśliciel uważany najczęściej za ojca współczesnego liberalizmu - którego dorobek bywa uznawany za jedyne istotne źródło inspiracji intelektualnej amerykańskich „Ojców-założycieli” - jawi się Straussowi jako polityczny hedonista, dla którego „życie jest smutnym poszukiwaniem radości" ${ }^{57}$, a jedyna ścieżka do tego, aby zwalczyć ból egzystencji, wiedzie przez posiadanie rzeczy dających największy zasób przyjemności.

Hobbesowskie pragnienie pozostania przy życiu przekształca się więc w pragnienie posiadania; życie ma trwać w sposób nie tylko znośny, ale i wygodny. Polityka łączy się z ekonomią, skupiając się na środkach bardziej eleganckich, aniżeli te roztrząsane w dziele Machiavellego. Według Straussa,

\footnotetext{
L. Strauss, Prawo naturalne..., s. 227.

Tamże, s. 228.

Tamże, s. 130. Por. K. I. Vaughn, John Locke's Theory of Property: Problems of Interpretation, „Literature of Liberty. A Review of Contemporary Liberal Thought" 1980, vol. III, nr 1, s. 14-15 i n. oraz: T. L. Pangle, The Spirit of Modern Republicanisms, Chicago 1990, zwłaszcza s. 141-171.
} 
„ekonomizm jest dojrzałym makiawelizmem” ${ }^{58}$. Takie rozumienie polityki wydaje się namacalną spuścizną myśli siedemnastowiecznej (której czołowych przedstawicieli - na co warto zwrócić uwagę - odczytano przez pryzmat dalekosiężnych konsekwencji rozwijanych przezeń stanowisk doktrynalnych ${ }^{59}$ ). U jej podstaw znajdujemy redefinicję pojęcia „natury”. Nie kryje się za nim wzorcowy porządek rzeczy, do jakiego odnoszono się w tradycji klasycznej; „natura” jest czymś obcym, z czym należy walczyć, obszarem wymagającym zawojowania, bądź też stanowi ogrom braków do wypełnienia. Myśl nowoczesna porzuca naturalne kryterium osądu ludzkiego postępowania czy sposobu życia, tracąc stopniowo kontakt ze zdroworozsądkowymi wyobrażeniami na temat dobra i zła ${ }^{60}$. Obywatele stają się oświeconymi jednostkami, których powszechnie dostępne zdobycze nauki uwalniają w końcu od prefilozoficznego oglądu spraw ludzkich.

Z kolei nowoczesny „filozof” pełni rolę służebną w społeczeństwie opartym na zasadach hedonizmu i ateizmu politycznego. „Celem filozofii nie jest już to, co można nazwać bezinteresowną kontemplacją tego, co wieczne, ale ulżenie doli człowieka" ${ }^{\text {"61 }}$. Warto w tym miejscu wyraźnie podkreślić, że tak opisana „pierwsza fala nowoczesności” nie zanikła pod naporem kolejnych wezbrań nowoczesnego myślenia. Jej wpływ uwidacznia się nadal w stylu życia nienasyconego konsumenta, dla którego państwo nie jest wspólnotą polityczną w rozumieniu wypracowanym przez Greków, lecz raczej mechanizmem służącym zabezpieczeniu wygody czy dobrobytu. Wpływ „pierwszej fali” odnajdujemy również na poziomie ładu instytucjonalnego, czyli w konkretnych rozwiązaniach ustrojowych państw liberalnodemokratycznych, ze Stanami Zjednoczonymi na czele.

P A W E E A R M D A

L. Strauss, Czym jest filozofia..., s. 100-101. Strauss dodaje: „nikt nie pojął tego głębiej niż Monteskiusz”. Autor O duchu praw „staje ostatecznie po stronie Anglii. Wyższość Anglii opiera się na wierze, iż Anglicy odnaleźli substytut dla surowej cnoty republikańskiej Rzymian. Substytutem tym jest handel i finanse" (tamże, s. 101). W takim wypadku postawienie Ameryki „w wyraźnej opozycji do Makiawelowskich zasad” oznaczałoby zapewne nic innego, jak przeciwstawienie eleganckiej czy „dojrzałej” wersji makiawelizmu jego pierwotnej postaci, obarczonej z zewnątrz (a być może bliższej przez to prawdziwego obrazu rzeczywistości) motywami działań brutalnych. Należy ponadto zauważyć, że Straussowskie odczytanie myśli Hobbesa i Locke'a jako ujmującej podstawy „zaborczego indywidualizmu” społeczeństwa nowoczesnego $\mathrm{w}$ istotnym sensie harmonizuje z podejściem niektórych autorów zainspirowanych przez marksizm. Zob. zwłaszcza L. Strauss, Review of C. B. Macpherson 'The Political Theory of Posessive Indyvidualism: Hobbes to Locke', [w:] tegoż, Studies in Platonic Political Philosophy, Chicago 1986, s. 229-231.

Por. N. Robertson, The Closing..., s. 3.

Zdanie Straussa, „nowe nauki polityczne od początku wyrzekają się całej dyskusji wokół fundamentalnego, najpilniejszego z pytań" (The Political Philosophy..., s. 152).

L. Strauss, Wykształcenie liberalne..., s. 270. 


\section{Abstract}

The article concerns Leo Strauss' approach to the legacy of Thomas Hobbes. There are two main accounts that are taken into consideration: the early one, presented in the book entitled 'Political Philosophy of Hobbes', published in 1936, and the later, coming from the most famous and influential work of Strauss, namely 'Natural Right and History' (1953), supplemented by two much shorter analyses in the essays: 'What Is Political Philosophy?' and 'The Three Waves of Modernity'. In the first case, Thomas Hobbes is depicted as the very founder of modern political philosophy. It is shown that his attempt to create new science of politics has its source in specific moral attitude and tends to make radical break with tradition moulded by Aristotelians. As for the second account of his thought, it is seriously modified by asserting, above all, that the act of creation of modernity should have been ascribed to Niccolo Machiavelli. Though, referring to ancient political orders, he formed the basis of entirely new solution, giving rise to the modern project of Enlightenement. This idea was based on ultimate denial of classical distinction between philosophers, i.e. men living their contemplative lives on the periphery of society, and non-philosophers, i.e. citizens devoted to their states and their sacred laws. Hobbes, however not in an explicit way, followed that path as the strongest adherent of the society free of religious prejudice, still causing disturbance or war when keeping all citizens from seeing things the way they really are. People must be made unwilling to die for what means nothing in the context of their mean worldly existence. It was political hedonism as well as political atheism that animated Hobbes' concept of 'natural rights'. According to Strauss, Hobbes may be justly described as a founder of liberalism, if conceived as a doctrine that focuses upon rights understood as certain subjective claims, and at the same time indicates the proper role of state to be their guarantee or guard. Fundamental principles governing political society might henceforth be found merely within the realm of human creation. Straussian interpretation of Hobbes reaches up to the legacy of John Locke. The latter, in fact, reinforced and radicalized new thought that has now taken a form of economism: what really counts in politics is to provide citizens with all the comfortable things that are possible to invent; citizen is a consumer. This is the spiritual result of the 'first way of modernity', which Hobbes belongs to. Its strictly political implication is institutional order, gradually implemented in all Western liberal democracies. Strauss' perspective on that prevailing kind of modern regime is hard to be clearly expressed but it seems authorised to state that the "American way of life", however defective, appears preferable to the Soviet or Nazi "modern solutions". 